\title{
KEMAMPUAN MENULIS TEKS EKSPLANASI SISWA KELAS 5 SEKOLAH DASAR MELALUI MODEL READ, ANSWER, DISSCUSS, EXPLAIN, AND CREATE
}

\author{
Dadan Setiawan ${ }^{1}$, Tatat Hartati ${ }^{2}$, Wahyu Sopandi ${ }^{3}$ \\ 1,2,3 Universitas Pendidikan Indonesia, Bandung \\ 1dsetiawan03@upi.edu, ${ }^{2}$ tatat@upi.edu, 3wsopandi@upi.edu
}

\begin{abstract}
Developing students' skills in writing scientific explanations is one of the goals in education. The purpose of this study was to determine the effect of the Read, Answer, Disscuss, Explain and, Create model (RADEC) on the ability to write explanatory texts in elementary school students. This research was conducted on 5th grade students of SDN 122 Cijawura, Buah Batu District, Bandung City. The research method used in this study was a quasi-experimental method with a nonequivalent pretest posttest control group design. Sample used in this study amounted to 38 students. According to this study, the pretest score of students' ability to write explanatory was 48,1 . After treatment, the result of posttest score of explanatory text writing skill was 68,9. Using t-test, the result of sig value obtained $=0.00$, so the results indicate positive effects of the RADEC model in improving the ability to write explanatory in elementary school students.
\end{abstract}

Keywords: Writing Ability, Explanatory Text, RADEC model.

\begin{abstract}
ABSTRAK
Mengembangkan keterampilan siswa dalam menulis penjelasan ilmiah adalah salah satu tujuan dalam pendidikan. Tujuan dari penelitian ini adalah untuk mengetahui pengaruh model Read, Answer, Disscuss, Explain and Create (RADEC) terhadap kemampuan menulis teks eksplanasi siswa sekolah dasar. Penelitian ini dilakukan pada siswa kelas 5 SDN 122 Cijawura, Kecamatan Buah Batu, Kota Bandung. Metode penelitian yang digunakan dalam penelitian ini adalah metode kuasi eksperimen dengan desain Non-equivalent pretest postest control grup design. Sampel yang digunakan dalam penelitian ini berjumlah 38 siswa. Dari penelitian ini didapatkan skor pretest kemampuan menulis teks eksplanasi siswa sebesar 48,1 sedangkan skor posttest sebesar 68,9. Hasil uji $t$ diperoleh hasil nilai $s i g=0,00$, sehingga ditafsirkan bahwa terdapat perbedaan yang signifikan kemampuan menulis teks eksplanasi siswa sebelum dan setelah diberikan treatment menggunakan model pembelajaran RADEC. Oleh sebab itu, dapat disimpulkan bahwa kemampuan menulis teks eksplanasi mengalami peningkatan dalam kategori cukup melalui model RADEC.
\end{abstract}

Kata kunci : Kemampuan Menulis, Teks Eksplanasi, Model RADEC. 
Pendas : Jurnal IImiah Pendidikan Dasar, ISSN Cetak : 2477-2143 ISSN Online : 2548-6950 Volume IV Nomor 1, Juni 2019

\section{A. Pendahuluan}

Keterampilan menulis merupakan keterampilan paling akhir yang dipelajari oleh siswa karena menulis merupakan proses kreatif melibatkan sistem yang kompleks. Dalam praktik menulis, siswa harus terampil memilih kosa kata yang tepat dan menggunakan bahasa yang jelas dan efektif agar hasil tulisan yang dibuat dapat dipahami dengan baik oleh pembaca (Tarigan, 2013). Seseorang yang mahir dalam menulis tentu melewati proses yang panjang untuk terus melatih kemampuannya secara berkesinambungan dan menggunakan strategi yang tepat. (Celce-Murcia, 2001; Akkaya \& Kirmizi, 2010).

Pembelajaran menulis di sekolah dasar memuat materi yang cukup beragam salah satunya adalah menulis teks eksplanasi. Menulis teks eksplanasi merupakan salah satu materi baru yang diajarkan di sekolah dasar sejak Kurikulum 2013 diberlakukan. Teks eksplanasi merupakan teks yang menjelaskan tentang proses terjadinya sesuatu dan mengapa sesuatu tersebut terjadi (Mahsun, 2014; Anderson \& Anderson, 1997a; Gerot \& Wignell, 1995; Derewianka, 1990). Sesuatu yang dijelaskan dalam teks eksplanasi ini berupa fenomena alam, sosial, maupun budaya (Priyatni, 2014). Teks eksplanasi merupakan jenis teks yang lebih rumit dibandingkan dengan berbagai teks yang lainnya. Oleh karena itu, tidak jarang siswa merasa kesulitan dalam menulis teks eksplanasi. Selain itu, menulis teks eksplanasi masih dipandang sulit karena materi teks eksplanasi merupakan materi yang baru sehingga keterampilan siswa dalam menulis teks eksplanasi harus terus ditingkatkan dengan tahapan belajar yang tepat (Emilia, 2012).

Pada saat ini, menulis masih belum menjadi suatu hal yang digemari oleh siswa, bahkan kegiatan menulis masih dianggap menjadi kegiatan yang sukar. Kondisi seperti ini membuat bangsa Indonesia menjadi kurang produktif dalam hal menulis karena kemampuan yang dimiliki oleh siswa masih rendah (Abidin, 2012). Rendahnya keterampilan menulis disebabkan oleh beberapa faktor diantaranya ialah minimnya peran guru dalam membina siswa agar terampil dalam menulis (Abidin, 2012). Lebih lanjut, faktor yang menyebabkan rendahnya kemampuan menulis siswa di Indonesia adalah penerapan strategi atau model pembelajaran yang kurang 
Pendas : Jurnal IImiah Pendidikan Dasar, ISSN Cetak : 2477-2143 ISSN Online : 2548-6950 Volume IV Nomor 1, Juni 2019

tepat. Penerapan model atau strategi pembelajaran yang kurang tepat dapat berdampak pada kemampuan dan prestasi belajar siswa (Joyce \& Calhoun, 2011). Selain itu, faktor lain yang menyebabkan rendahnya kemampuan menulis siswa karena minimnya motivasi dan dorongan dari guru Graham \& Hall, 2016; Özdemir \& Aydın, 2015).

Berdasarkan permasalahan di atas, rendahnya kemampuan menulis siswa khususnya di sekolah dasar harus segera di atasi. Salah satu cara untuk mengatasi permasalahan tersebut adalah dengan menerapkan model pembelajaran inovatif. Salah satu model pembelajaran inovatif adalah model pembelajaran RADEC. Model RADEC merupakan model pembelajaran yang berorientasi pada penguasaan kompetensi dan keterampilan abad ke-21. Model RADEC memiliki beberapa keunggulan diantaranya yaitu mengembangkan keterampilan berkomunikasi, bekerjasama, dan membantu siswa beroleh pemahaman konseptual. Pemahaman konseptual mengenai ilmu pengetahuan atau fenomena yang ingin dijelaskan merupakan salah satu hal penentu dalam menulis teks eksplanasi. Dengan keunggulan model
RADEC tersebut, diharapkan model ini dapat mengembangkan kemampuan siswa dalam menulis teks eksplanasi.

\section{B. Landasan Teori}

\section{Kemampuan Menulis}

Menulis merupakan salah satu keterampilan berbahasa yang harus dikuasai oleh siswa. Menulis merupakan tingkatan tertinggi dari keterampilan berbahasa yang lainnya yaitu keterampilan membaca, menyimak dan berbicara. Selain itu, menulis merupakan kegiatan yang sangat penting karena dengan kegiatan menulis dapat mengembangkan keterampilan siswa dalam berpikir kritis dan kreatif. Sehingga keterampilan berpikir kritis dan kreatif siswa menjadi meningkat. Hal ini sejalan dengan apa yang telah dikemukakan oleh Bakry \& Alsamadani (2015) yang menyatakan bahwa dengan menulis dapat membantu perkembangan sosial, meningkatkan berpikir kritis dan meningkatkan berpikir kreatif siswa.

Pada dasarnya, proses menulis memerlukan tingkat berpikir yang tinggi dan memerlukan kreativitas agar tulisan-tulisan yang dihasilkan memiliki kualitas yang baik dan menarik. Keterampilan menulis, merupakan keterampilan yang harus dikuasai oleh 
Pendas : Jurnal IImiah Pendidikan Dasar, ISSN Cetak : 2477-2143 ISSN Online : 2548-6950 Volume IV Nomor 1, Juni 2019

siswa, mengingat kegiatan menulis merupakan kegiatan yang ada dalam setiap proses pembelajaran dengan tujuan untuk memudahkan siswa dalam mengingat dan atau mempelajari sesuatu. Senada dengan hal tersebut, Graham \& Hall (2016) juga mengungkapkan bahwa keterampilan menulis merupakan keterampilan yang sangat penting dan harus dikuasai oleh siswa di sekolah. Keterampilan menulis sering digunakan untuk menguji pemahaman siswa terhadap materi yang telah dipelajari. Oleh karena itu, siswa harus memiliki keterampilan menulis yang baik agar mempermudah dalam mempelajari sesuatu yang ingin dipelajari.

Menulis merupakan aktivitas berpikir tingkat tinggi karena melibatkan kognitif, kreativitas, dan sikap. Dalam hal ini menulis merupakan suatu proses atau aktivitas yang produktif karena dapat menghasilkan produk atau karya tulis yang dapat dijadikan sebagai alat penyampai pesan atau alat untuk berkomunikasi (Cahyani, 2012; Tarigan, 2013; Abidin, 2015). Hal tersebut sejalan dengan Ozdemir \& Aydin (2015) yang mengungkapkan bahwa keterampilan membaca dan menulis merupakan keterampilan berbahasa yang produktif.
Mengajarkan

keterampilan

menulis di sekolah dasar bukanlah suatu hal yang mudah. Untuk melatih siswa agar terampil dalam menulis membutuhkan strategi yang tepat dan membutuhkan kesabaran dalam membimbing siswa ketika proses menulis. Hal ini sejalan dengan apa yang dikemukakan oleh Pardo (2006) yang mengemukakan bahwa pengajaran menulis tidaklah mudah karena membutuhkan proses dan waktu yang cukup. Dalam praktiknya, karena menulis bukanlah sesuatu yang sekali jadi, maka guru harus memberikan kesempatan kepada siswa untuk melakukan tahap pengecekan kembali dan mengeditnya jika terdapat kesalahan. Tahap tersebut penting dilakukan untuk meminimalisir kesalahan yang dilakukan oleh penulis (Hartati \& Cuhariah, 2015).

\section{Teks Eksplanasi}

Pada pembelajaran menulis di sekolah dasar, terdapat beragam jenis teks yang diajarkan kepada siswa. Berdasarkan Peraturan Mentri Pendidikan dan Kebudayaan No. 24 Tahun 2016 tentang Kompetensi Inti dan Kompetensi Dasar Pelajaran pada Kurikulum 2013, salah satu jenis teks yang diajarkan di sekolah dasar adalah teks eksplanasi. Teks eksplanasi 
Pendas : Jurnal Ilmiah Pendidikan Dasar, ISSN Cetak : 2477-2143 ISSN Online : 2548-6950 Volume IV Nomor 1, Juni 2019

merupakan teks yang termasuk dalam genre teks tanggapan.

Genre teks tanggapan, secara umum terdiri dari dua jenis yaitu teks transaksional dan teks ekspositori. Dilihat dari kedua jenis teks tangapan ini, teks eksplanasi termasuk dalam jenis teks ekspositori (Kemendikbud, 2014).

Banyak ahli yang berpendapat tentang definisi dari teks eksplanasi. Menurut priyatni (2014, hlm. 82) mengemukakan bahwa teks eksplanasi merupakan teks yang berisi penjelasan tentang proses terjadinya fenomena alam, sosial, ilmu pengetahuan dan budaya. Sejalan dengan pendapat tersebut terdapat pula ahli yang mendefinisikan teks eksplanasi sebagai teks yang menjelaskan tentang proses terjadinya sesuatu dan mengapa sesuatu tersebut terjadi (Mahsun, 2014; Anderson \& Anderson, 1997a; Gerot \& Wignell, 1995; Derewianka, 1990).

Teks eksplanasi memiliki fungsi untuk menjelaskan proses terjadinya suatu gejala atau fenomena yang terjadi. Selain itu, teks eksplanasi juga berfungsi sebagai sarana untuk memahami dunia dan cara kerjanya (Knapp \& Watkins, 2005). Dilihat dari pengertian dan fungsi teks eksplanasi, maka teks eksplanasi memiliki tujuan.
Tujuan dari teks eksplanasi sendiri adalah untuk mengungkapkan secara jelas bagaimana proses terjadinya sesuatu, bagaimana cara kerja sesuatu, dan mengungkapkan bagaimana suatu fenomena itu bisa terjadi (Emilia, 2012).

Secara umum, teks eksplanasi terbagi dalam beberapa bagian yakni: (a) judul; (b) pernyataan umum; (c) bagian inti dari teks eksplanasi yang merupakan penjelasan tentang kejadian atau tahapan dari suatu proses; dan (d) penutup (Mahsun, 2014; Emilia, 2012; Anderson \& Anderson, 1997a). Senada dengan hal tersebut, Priyatni (2014, hlm. 82) juga mengemukakan bahwa struktur teks eksplanasi terbagi dalam empat bagian yaitu: (a) judul; (b) bagian pembuka yang berisi tentang pernyataan umum; (c) bagian inti yang menjelaskan tentang bagaimana cara kerja suatu alat atau bagaimana suatu fenomena terjadi dan mengapa fenomena tersebut terjadi; dan (d) bagian penutup yang berisi kesimpulan dan atau hasil interpretasi penulis.

\section{Model Pembelajaran RADEC}

Model pembelajaran RADEC dikembangkan oleh Sopandi (2017) dengan tujuan untuk meningkatkan kualitas pembelajaran dan mendorong 
Pendas : Jurnal IImiah Pendidikan Dasar, ISSN Cetak : 2477-2143 ISSN Online : 2548-6950 Volume IV Nomor 1, Juni 2019

siswa untuk menguasai kompetensi dan keterampilan abad ke-21 yang dibutuhkan. Model ini merupakan model yang sudah disesuaikan dengan konteks keindonesiaan. Model ini memiliki langkah-langkah pembalajaran yang dapat mendorong siswa untuk belajar secara aktif dan produktif.

Model RADEC dikembangkan atas dasar beberapa hal yaitu berikut. Pertama, model ini didasarkan pada tujuan pendidikan nasional yakni untuk mengembangkan segenap potensi yang dimiliki siswa menjadi manusia yang beriman kepada Tuhan, luhur, sehat, berpengetahuan, cakap, kreatif, mandiri, dan menjadi warga negara yang demokratis serta bertanggung jawab (Pemerintah Republik Indonesia, 2003). Kedua, model ini dikembangkan atas dasar teori kontruktivisme. Menurut Vygotski (dalam Sopandi, 2017) mengemukakan bahwa kemampuan kognitif pada anak-anak dapat berkembang melalui interaksi dengan lingkungan sosial. Pada teori ini, dikenal dengan istilah Zona Pengembangan Proksimal (ZPD). Jadi dalam proses pembelajaran, ada masa dimana siswa perlu belajar secara mandiri tentang suatu konsep materi pelajaran tanpa bantuan oleh orang lain. Hal ini bertujuan untuk melihat kemampuan sebenarnya siswa dan ada masa dimana siswa perlu bantuan orang lain untuk mengembangkan kemampuan potensialnya. Atas dasar teori tersebut, maka dalam proses pembelajaran guru harus melakukan pembelajaran diantara hal tersebut.

Model pembelajaran RADEC memiliki beberapa keunggulan diantaranya yaitu dapat mendorong siswa untuk beroleh keterampilan abad ke-21. Pada abad ke-21 ini ada beberapa kompetensi yang harus dimiliki oleh manusia yaitu pemahaman konseptual, berpikir kritis, kolaborasi dan komunikasi, dan berpikir kreatif (morocco, et. al., 2008). Keunggulan model RADEC lainnya adalah tahapan dari model ini mudah untuk dipahami dan diingat oleh guru. Hal ini terbukti dari penelitian yang dilakukan oleh Handayani \& Sopandi (2018) yang hasilnya adalah sebanyak $97,2 \%$ guru yang mengikuti pelatihan tertarik untuk mengimplementasikan model pembelajaran RADEC di sekolah karena mudah untuk dipahami dan hasil implementasi di sekolahnya pun dapat membantu siswa untuk membangun karakter, meningkatkan pemahaman konseptual siswa dan mendorong siswa untuk 
Pendas : Jurnal IImiah Pendidikan Dasar, ISSN Cetak : 2477-2143 ISSN Online : 2548-6950 Volume IV Nomor 1, Juni 2019

mengembangkan kompetensi abad ke21.

Langkah-langkah model RADEC dikemukakan oleh Sopandi (2017) yaitu Read, Answer, Disscuss, Explain and Create. Secara lebih rinci penjelasan dari setiap tahapan model RADEC adalah sebagai berikut.

\section{a. Read (Baca)}

Pada langkah ini, siswa membaca informasi dari berbagai sumber. Sumber yang dibaca siswa bisa berupa buku, sumber informasi cetak maupun dari internet. Upaya mendorong siswa untuk memahami informasi, siswa diberikan pertanyaan prapembelajaran. Pertanyaan-pertanyaan yang diberikan kepada siswa adalah pertanyaan yang berkaitan dengan bahan yang akan dipelajari. Pertanyaan prapembelajaran yang diberikan tentu bukanlah pertanyaan yang hanya bersifat low order thinking (LOT) akan tetapi pertanyaan yang diberikan adalah pertanyaan-pertanyaan yang menuntut siswa untuk berpikir tingkat tinggi. Kegiatan membaca ini dilakukan oleh siswa di luar kelas atau di rumah sebelum proses pembelajaran dilakukan. Kegiatan ini dilakukan sebagai upaya efektivitas proses belajar mengajar yang selama ini menjadi hambatan bagi guru dalam menerapkan model pembelajaran tertentu. Selain itu kegiatan membaca prapembelajaran di luar waktu pembelajaran ini didasarkan pada siswa dapat memperoleh sendiri beberapa informasi yang dibutuhkan tanpa harus dijelaskan oleh guru atau bantuan dari orang lain.

\section{b. Answer (Jawab)}

Pada tahap ini, siswa menjawab pertanyaan prapembelajaran pada lembar kerja siswa. Melalui kegiatan ini siswa dapat membuktikan bahwa siswa mampu belajar secara mandiri dan siswa pun dapat mengidentifikasi hal apa saja yang menjadi kesulitan siswa dalam menjawab pertanyaan prapembelajaran. Pertanyaanpertanyaan prapembelajaran yang diberikan guru kepada siswa dapat mendorong siswa untuk beroleh pemahaman yang lebih terhadap informasi yang dibacanya.

c. Disscuss (Diskusi)

Pada tahap diskusi, siswa belajar secara berkelompok untuk mendiskusikan jawaban siswa dari pertanyaan prapembelajaran. Pada kegiatan ini, guru mendorong siswa untuk berdiskusi secara aktif. Guru juga memberikan motivasi kepada siswa 
Pendas : Jurnal IImiah Pendidikan Dasar, ISSN Cetak : 2477-2143 ISSN Online : 2548-6950 Volume IV Nomor 1, Juni 2019

yang berhasil menyelesaikan tugas dan menjawabnya dengan baik. Pada siswa yang belum berhasil menyelesaikan tugasnya guru memberikan motivasi dan guru memberikan kesempatan kepada siswa yang belum menguasai materi pembelajaran untuk bertanya kepada siswa yang sudah menguasainya.

\section{d. Explain (Menjelaskan)}

Pada tahap ini, siswa diminta untuk menjelaskan secara klasikal terkait materi yang telah didiskusikan. Dalam kegiatan ini, guru memastikan bahwa apa yang dijelaskan oleh penyaji secara ilmiah benar dan dapat dipahami oleh siswa lain. Selain itu, guru juga mendorong siswa lain untuk bertanya, menyanggah, atau menambah apa yang telah disampaikan oleh temannya dari kelompok lain. Selain siswa yang melakukan presentasi. Pada tahap ini, guru juga dapat menjelaskan materi penting yang esensial.

e. Create (Mencipta)

Pada tahap ini, guru memberikan dorongan dan menginspirasi siswa agar menggunakan pengetahuan yang dikuasainya untuk menghasilkan ide penelitian dan pemecahan masalah yang kemudian hasil akhir dari pemecahan masalah tersebut dapat berupa produk. Produk yang dihasilkan bisa berbentuk karya tulis, poster, membuat teknologi sederhana dan lain sebagainya. Sebagai upaya merangsang ide-ide kreatif siswa guru dapat menginspirasi siswa dengan memberikan contoh rencana kreatif yang mungkin tidak terpikirkan oleh siswa padahal hal tersebut sangat dekat dengan lingkungannya. Dalam hal ini, karena penelitian ini berorientasi untuk melihat kemampuan menulis siswa, maka pada tahap mencipta ini siswa diorientasikan pada pembuatan karya tulis teks eksplanasi. Proses menulis yang dilakukan oleh siswa melalui tahapan dalam pembelajaran menulis yaitu tahap pramenulis, tahap menulis dan tahap pascamenulis (Dalman, 2014).

\section{Metode}

\section{Desain}

Metode penelitian yang digunakan dalam penelitian ini adalah metode penelitian kuasi eksperimen dengan desain Non-equivalent pretest postest control grup design. Metode kuasi eksperimen adalah metode yang digunakan untuk menyelidiki hubungan sebab akibat dari adanya pemberian perlakuan terhadap kelompok 
Pendas : Jurnal Ilmiah Pendidikan Dasar, ISSN Cetak : 2477-2143 ISSN Online : 2548-6950 Volume IV Nomor 1, Juni 2019

eksperimen dan kelompok kontrol (Creswell, 2017; Sugiyono, 2017).

\section{Sampel}

Data dikumpulkan dari satu kelas yang berjumlah 38 siswa. Sampel dalam penelitian ini adalah kelas VB di SDN 122 Cijawura. Sekolah tersebut terletak di Kecamatan Buah Batu, Kota Bandung. Siswa yang menjadi sampel dalam penelitian ini merupakan siswa yang secara kognitif berbeda-beda. Terdapat siswa yang secara kognitif berada pada level tinggi, terdapat siswa yang berada pada level menengah dan terdapat siswa yang secara kognitif berada pada level rendah.

\section{Instrumen}

Pengumpulan data kemampuan menulis teks eksplanasi siswa menggunakan intrumen tes dan rubrik penilaian. Rubrik penilaian kemampuan menulis teks eksplanasi dikembangkan oleh peneliti dengan mengacu pada pedoman penilaian yang dikembangkan oleh beberapa ahli bahwa hal yang dinilai dalam kemampuan menulis teks eksplanasi adalah teks eksplanasi yang dibuat harus sesuai dengan karakteristik teks eksplanasi dan kaidah bahasa teks eksplanasi (Rose, 2006; Knapp \& Watkins, 2005; Department of Western
Australia, 1997a). Berikut ini adalah indikator penilaian kemampuan menulis teks eksplanasi yang dikembangkan oleh peneliti yaitu: (a) struktur teks eksplanasi; (b) isi teks eksplanasi; (c) bahasa teks eksplanasi; dan (d) aspek mekanik.

\section{Prosedur}

Dalam prosedur pelaksanaan penelitian ini, diawali dengan peneliti mencari sebuah permasalahan yang dihadapi oleh siswa sekolah dasar khususnya dalam pembelajaran menulis. Setelah peneliti mendapatkan suatu permasalahan, baru kemudian peneliti membuat rumusan masalah dan menentukan tujuan dari penelitian yang akan dilakukan. Selanjutnya, peneliti melakukan kajian literatur mengenai permasalahan yang sedang dihadapi. Setelah itu, peneliti menentukan rancangan pembelajaran yang efektif untuk mengentaskan permasalahan dalam pembelajaran menulis. Adapun solusi yang didapat oleh peneliti adalah penerapan model pembelajaran. Model pembelajaran yang ditawarkan sebagai solusi untuk mengentaskan kemampuan menulis teks eksplanasi adalah model pembelajaran RADEC. Selanjutnya, peneliti menentukan sampel penelitian. Setelah itu, peneliti membuat 
Pendas : Jurnal Ilmiah Pendidikan Dasar, ISSN Cetak : 2477-2143 ISSN Online : 2548-6950

Volume IV Nomor 1, Juni 2019

instrumen penelitian. Instrumen penelitian ini selanjutnya divalidasi oleh dua orang ahli dalam pembelajaran menulis di sekolah dasar. Setelah instrumen penelitian sudah divalidasi, baru kemudian peneliti melakukan pengambilan data. Proses pengambilan data dalam penelitian ini dilakukan sebanyak delapan kali pertemuan. Pertemuan pertama, peneliti melakukan pretest untuk mengetahui kemampuan menulis teks eksplanasi siswa sebelum diberikan treatment.

Pada pertemuan kedua sampai pertemuan ke tujuh siswa diberikan pembelajaran menggunakan model RADEC. Setelah diberikan treatment, selanjutnya dilakukan posttest untuk mengetahui kemampuan menulis teks eksplanasi siswa setelah diberikan treatment.

Setelah diperoleh data hasil pretest dan posttest, selanjutnya data dianalisis. Analisis hasil penelitian dilakukan menggunakan uji normalitas, uji homogenitas dan Uji $t$. Dalam pengolahan datanya, peneliti menggunakan program SPSS versi 20. Uji $t$ digunakan untuk melihat perbedaan rata-rata kemampuan menulis teks eksplanasi siswa sebelum dan setelah diberikan treatment menggunakan model RADEC.

\section{Hasil dan Pembahasan}

1. Hasil

Berdasarkan hasil skor posttest menunjukkan kemampuan menulis teks eksplanasi siswa lebih baik dibandingkan dengan hasil skor pretest. Pada tabel 1 dan tabel 2 di bawah ini, menunjukkan perbedaan kemampuan menulis teks eksplanasi siswa dilihat pada empat indikator yaitu struktur teks eksplanasi, isi, bahasa, dan aspek mekanik. Perbedaan tersebut dapat dilihat pada tabel berikut.

Tabel 1. Hasil Pretest

\begin{tabular}{lcccc}
\hline & Struktur & Isi & Bahasa & Mekanik \\
\hline Mean & 48.68 & 51.31 & 51.97 & 40.78 \\
Median & 50 & 50 & 50 & 50 \\
Std. & 12.928 & 19.231 & 17.802 & 22.082 \\
Deviation & & & & \\
Variance & 167.141 & 369.844 & 316.945 & 216.927 \\
Range & 50 & 50 & 50 & 50 \\
Minimum & 25 & 25 & 25 & 25 \\
Maximum & 75 & 75 & 75 & 75 \\
\hline
\end{tabular}

Berdasarkan tabel 1 di atas, data menunjukkan bahwa kemampuan awal siswa dalam menulis teks eksplanasi termasuk dalam kategori kurang. Skor minimum dari setiap aspek menulis teks eksplanasi yang diperoleh siswa sebesar 25, sedangkan skor maksimum dari setiap aspeknya sebesar 75. Aspek yang paling 
Pendas : Jurnal Ilmiah Pendidikan Dasar, ISSN Cetak : 2477-2143 ISSN Online : 2548-6950 Volume IV Nomor 1, Juni 2019

menonjol diantara empat indikator kemampuan menulis teks eksplanasi siswa adalah aspek struktur. Artinya kemampuan menulis teks eksplanasi siswa sesuai dengan struktur teks eksplanasi pada kegiatan pretest mendapatkan skor rata-rata tertinggi diantara aspek yang lainnya.

Tabel 2. Hasil Posttest

\begin{tabular}{lcccc}
\hline & Struktur & Isi & Bahasa & Mekanik \\
\hline Mean & 76.31 & 69.07 & 74.34 & 55.92 \\
Median & 75 & 75 & 75 & 50 \\
Std. & 22.471 & 22.082 & 21.345 & 22.082 \\
Deviation & & & & \\
Variance & 504.979 & 487.642 & 455.637 & 487.642 \\
Range & 75 & 75 & 75 & 75 \\
Minimum & 25 & 25 & 25 & 25 \\
Maximum & 100 & 100 & 100 & 100 \\
\hline
\end{tabular}

Berdasarkan data posttest pada tabel 2, diketahui bahwa terdapat peningkatan kemampuan menulis setelah diberikan pembelajaran menggunakan model RADEC. Skor maksimum yang semula mendapat skor 75, setelah diberikan treatment naik menjadi 100. Aspek yang paling menonjol diantara empat indikator kemampuan menulis teks eksplanasi siswa adalah aspek struktur. Artinya kemampuan menulis teks eksplanasi siswa sesuai dengan struktur teks eksplanasi pada kegiatan posttest mengalami peningkatan tertinggi diantara aspek yang lainnya. Peningkatan dari setiap indikator kemampuan menulis teks eksplanasi siswa berdasarkan data pretest dan posttest dapat dilihat pada gambar di bawah ini yaitu sebagai berikut.

\section{Gambar 1. Peningkatan Kemampuan Menulis Teks Eksplanasi}

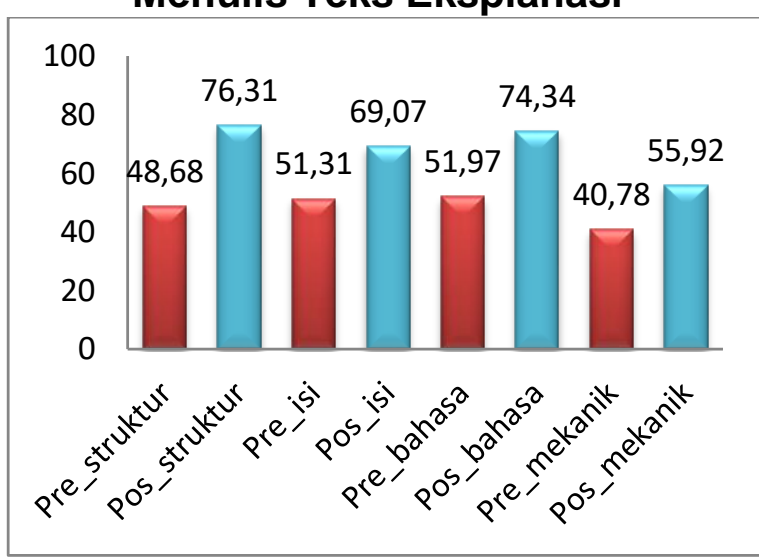

Berdasarkan gambar 1, data menunjukkan terjadi peningkatan pada setiap indikator kemampuan menulis teks eksplanasi. Peningkatan yang paling signifikan terjadi pada indikator struktur teks eksplanasi. Hal ini terlihat dari data pretest pada aspek struktur yaitu sebesar 48,68 sedangkan skor posttest sebesar 76.31. Sementara peningkatan yang tidak terlalu menonjol terlihat pada aspek mekanik. Skor rata-rata pretest pada aspek mekanik yaitu sebesar 40,78 sedangkan skor rata-rata posttest adalah sebesar 55.92. Artinya peningkatan siswa pada aspek mekanik tidak terlalu besar dibandingkan peningkatan kemampuan menulis siswa pada aspek lain. 
Pendas : Jurnal Ilmiah Pendidikan Dasar, ISSN Cetak : 2477-2143 ISSN Online : 2548-6950 Volume IV Nomor 1, Juni 2019

Sekait dengan penjelasan di atas, kemampuan menulis teks eksplanasi secara keseluruhan dapat dilihat dari hasil uji dua rerata pretest dan posttest pada tabel 3 berikut.

Tabel 3. Pretest, Posttest dan Uji $t$ Kemampuan Menulis Teks Eksplanasi

\begin{tabular}{lll}
\hline & Pretest & Posttest \\
\hline $\mathrm{N}$ & 38 & 38 \\
Rata-rata & 48.1 & 68.9 \\
Std. Deviation & 13.546 & 19.521 \\
Uji Normalitas & 0.27 & 0.75 \\
Uji Homogenitas & 0.02 & 0.02 \\
Uji t' & 0.00 & 0.00 \\
\hline
\end{tabular}

Berdasarkan tabel di atas, telah diperoleh hasil bahwa nilai rata-rata pretest sebesar 48,1 dengan kategori kurang dan nilai rata-rata posstest sebesar 68,9 dengan kategori cukup. Berdasarkan uji normalitas yang dilakukan telah menunjukkan bahwa data tersebut semuanya berdistribusi normal tapi tidak homogen. Karena data tersebut tidak homogen, maka peneliti melanjutkan analisis data menggunakan uji $t$. dari hasil uji $t^{\prime}$ diperoleh hasil bahwa nilai signifikansinya adalah $0.000<0,05$ artinya $\mathrm{H}_{0}$ ditolak. Dengan demikian dapat disimpulkan bahwa terdapat perbedaan secara signifikan kemampuan menulis teks eksplanasi siswa antara sebelum dan sesudah diberikan treatment menggunakan model pembelajaran RADEC.

\section{Pembahasan}

Kemampuan menulis teks eksplanasi siswa melalui penerapan model pembelajaran RADEC mengalami peningkatan secara signifikan. Hal ini terlihat dari perolehan nilai rata-rata pretest sebesar 48,1 sedangkan nilai rata-rata posttest sebesar 68,9. Selanjutnya, berdasarkan uji perbedaan dua rerata menggunakan uji paired-sample t-test telah diketahui nilai signifikansinya adalah $0.000<0.05$ artinya $\mathrm{H}_{0}$ ditolak. Hal ini berarti terdapat perbedaan yang signifikan nilai rata-rata kemampuan menulis teks eksplanasi siswa pada saat pretest dan posttest. Dengan demikian, dapat disimpulkan bahwa model RADEC efektif dalam meningkatkan kemampuan menulis teks eksplanasi siswa.

Dalam menulis, komponen kognitif berpengaruh secara signifikan dalam meningkatkan kemampuan siswa dalam menulis (Decker, Roberts, Roberts, \& Stafford, 2016). Hal ini dikarenakan menulis adalah kegiatan berpikir tingkat tinggi yang melibatkan sistem yang kompleks, sehingga untuk bisa menulis dengan baik, siswa harus berupaya dengan keras diiringi intensitas membaca yang tinggi (Akkaya \& Kirmizi, 2010). Model 
Pendas : Jurnal IImiah Pendidikan Dasar, ISSN Cetak : 2477-2143 ISSN Online : 2548-6950

Volume IV Nomor 1, Juni 2019

RADEC memberikan dampak positif kepada siswa melalui langkah-langkah pembelajaran yang mendorong siswa untuk beroleh pemahaman yang tinggi. Pengetahuan dan pemahaman siswa yang kuat mengenai sebuah teks dan ilmu pengetahuan yang dipelajari dapat memudahkan siswa dalam menuangkan ide yang dimilikinya kedalam bentuk tulisan (Alexander, DePalma, \& Ringer, 2016). Selain itu, dalam praktiknya guru hanya berperan sebagai fasilitator. Siswa yang dituntut untuk aktif dalam proses pembelajaran. Pembelajaran yang mendorong siswa untuk terlibat secara aktif akan membuat pembelajaran menjadi lebih bermakna (Navehebrahim, 2011). Dalam proses menentukan permasalahan dan topik yang akan dijelaskan oleh siswa dalam bentuk teks eksplanasinya juga melibatkan siswa dalam pengambilan keputusan. Hal tersebut berdampak pada meningkatnya motivasi dan tanggung jawab siswa dalam proses pembelajaran (Bonyadi \& Zeinalpur, 2014).

Langkah-langkah model RADEC terbukti mampu meningkatkan kemampuan menulis teks eksplanasi siswa. Indikator yang paling mengalami peningkatan tertinggi adalah pada indikator struktur teks eksplanasi. Indikator yang peningkatannya tidak signifikan adalah pada indikator aspek mekanik. Pada aspek mekanik siswa masih terdapat banyak kesalahan dalam kaidah ejaan.

Dilihat dari aspek struktur, siswa telah mampu menulis teks eksplanasi sesuai dengan struktur teks eksplanasi yang terdiri dari bagian pernyataan umum, urutan sebab-akibat dan kesimpulan. Hal ini berarti bahwa siswa memiliki pemahaman konsep yang baik tentang teks eksplanasi. Hal ini sejalan dengan keunggulan dari model pembelajaran RADEC yakni mendorong siswa untuk beroleh pemahaman konsep yang baik terhadap materi yang dipelajari. Sejalan dengan hal tersebut, Handayani \& Sopandi (2018) juga menyatakan dalam hasil penelitiannya bahwa melalui model RADEC dapat membantu siswa beroleh pemahaman yang baik terhadap materi yang dipelajari. Selain itu, terdapat penelitian lain yang menunjukkan bahwa model RADEC dapat mendorong siswa untuk beroleh pemahaman konseptual yang baik yakni penelitian yang dilakukan oleh Lukmannudin (2018) bahwa penguasaan konsep IPA dan kemampuan menjelaskan fenomena 
Pendas : Jurnal Ilmiah Pendidikan Dasar, ISSN Cetak : 2477-2143 ISSN Online : 2548-6950

Volume IV Nomor 1, Juni 2019

mengalami peningkatan setelah diberikan pembelajaran menggunakan model RADEC.

\section{E. Kesimpulan}

Berdasarkan hasil analisis data dan pembahasan yang telah dipaparkan pada penjelasan di atas, maka kesimpulan dalam penelitian ini adalah kemampuan menulis teks eksplanasi siswa mengalami peningkatan secara signifikan setelah diberikan pembelajaran menggunakan model pembelajaran RADEC. Peningkatan kemampuan menulis siswa dapat dilihat dari perolehan nilai rata-rata pretest yang didapat siswa sebesar 48,1 dan nilai rata-rata posstest sebesar 68,9. Kemudian berdasarkan hasil uji dua rerata nilai pretest dan posstest menggunakan uji $t$ ' telah diperoleh hasil bahwa nilai signifikansinya adalah $0.000<0.05$ artinya HO ditolak, sehingga dapat disimpulkan bahwa terdapat perbedaan yang signifikan kemampuan menulis teks eksplanasi siswa antara sebelum dan sesudah diberikan treatment menggunakan model RADEC.

\section{DAFTAR PUSTAKA}

Buku:

Abidin, Y. (2012). Pembelajaran Bahasa Berbasis Pendidikan Karakter. Bandung: Refika Aditama.
Abidin, Y. (2015). Pembelajaran Multiliterasi Sebuah Jawaban atas Tantangan Pendidikan Abad Ke-21 dalam Konteks Keindonesiaan. Bandung: Refika Aditama.

Anderson, M \& Anderson, K. 1997a. Text Types in English 1. Melbourne: Macmillan Education Australia.

Cahyani, I. (2012). Pembelajaran Menulis Berbasis Karakter dengan Pendekatan Experiental Learning. Bandung: Program Studi Pendidikan Dasar SPS UPI.

Celce-Murcia, M. (2001). Teaching English as a second or foreign language (3th ed.). Boston: Heinle \& Heinle.

Creswell, J. W. (2017). Research Design Pendekatan Kualitatif, Kuantitatif dan Mixed. Yogyakarta: Pustaka Pelajar.

Dalman, H. (2014). Keterampilan Menulis. Jakarta: Rajawali Pers.

Derewianka, B. (1990). Exploring How Text Work. Newtown: PETA.

Education Department of Western Australia. (1997a). Writing resource book. Port Melbourne: Henemann.

Emilia, E. (2012). Pendekatan GenreBased dalam Pengajaran Bahasa Inggris: Petunjuk untuk Guru. Bandung: Riqi Press.

Gerot, L. \& Wignell. (1995). Making Sense of Functional Grammar. Australia: Gerd Stabler.

Hartati, T. \& Cuhariah, Y. (2015). Pendidikan Bahasa dan Sastra Indonesia. Bandung: UPI PRESS.

Joyce, B. Weil, M. \& Calhoun, E. (2011). Models of Teaching. Yogyakarta: Pustaka Pelajar.

Kemendikbud. (2014). Buku Guru Bahasa Indonesia Wahana Pengetahuan Jakarta: Kemendikbud.

Knapp, P \& Watkins. (2005). Genre, Text, Grammar Technologies for Teaching and Assessing Writing. 
Pendas : Jurnal Ilmiah Pendidikan Dasar, ISSN Cetak : 2477-2143 ISSN Online : 2548-6950 Volume IV Nomor 1, Juni 2019

Sydney: University of New South Wales.

Lukmanudin. (2018). Penguasaan Konsep IPA dan Kemampuan Menjelaskan Fenomena Perpindahan Zat Pencemar Melalui Pembelajaran RADEC (Tesis, Universitas Pendidikan Indonesia, 2012).

Mahsun, (2014). Teks dalam Pembelajaran Bahasa Indonesia. Jakarta: Rajawali Pers.

Morocco, C. C., et. al (2008). Supported Literacy for Adolescents. Transforming Teaching and Content Learning for The TwentyFirst Century. San Fransisco: Jossey-Bass Awiley Imprint.

Pemerintah Republik Indonesia. (2003). Undang-Undang Republik Indonesia Nomor 20 Tahun 2003 tentang Sistem Pendidikan Nasional. Sekretariat Negara Republik Indonesia. Jakarta.

Priyatni, E.T. (2014). Desain Pembelajaran Bahasa Indonesia dalam Kurikulum 2013. Jakarta: Bumi Aksara.

Republik Indonesia, Peraturan Mentri Pendidikan dan Kebudayaan, Nomor 24, 2016, tentang Kompetensi Inti dan Kompetensi Dasar Pelajaran pada Kurikulum 2013 pada Pendidikan Dasar dan Pendidikan Menengah.

Rose, D. (2007). Reading to learn learning to read. Assessing Students Writing. Melbourne: Catholic Education Office of Melbourne.

Sugiyono. (2017). Metode Penelitian Kuantitatif, Kualitatif, dan R\&D. Bandung: Alfabeta.

Tarigan, H.G. (2013). Menulis Sebagai Suatu Keterampilan Berbahasa. Bandung: Angkasa.
Jurnal:

Akkaya, N., \& Kirmizi, F. S. (2010). Relationship between attitudes to reading and time allotted to writing in primary education. Procedia Social and Behavioral Sciences, 2(2), 4742-4746. https://doi.org/10.1016/..sbspro.20 10.03.761.

Alexander, K. P., DePalma, M. J., \& Ringer, J. M. (2016). Adaptive Remediation and the Facilitation of Transfer in Multiliteracy Center Contexts. Computers and Composition, 41, 32-45. https://doi.org/10.1016/j.compco m.2016.04.005.

Bakry, M. S., \& Alsamadani, H. A. (2015). Improving the Persuasive Essay Writing of Students of Arabic as a Foreign Language (AFL): Effects of Self-Regulated Strategy Development. Procedia Social and Behavioral Sciences, 182, 89-97. https://doi.org/10.1016/.j.sbspro.20 15.04.742.

Bonyadi, A., \& Zeinalpur, S. (2014). Perceptions of Students Towards Self-selected and Teacherassigned Topics in EFL Writing. Procedia - Social and Behavioral Sciences, 98, 385-391. https://doi.org/10.1016/j.sbspro.2 014.03.430.

Decker, S. L., Roberts, A. M., Roberts, K. L., \& Stafford, A. L. (2016). Cognitive components of developmental writing skill, 53(6). https://doi.org/10.1002/pits.

Graham, S., \& Hall, T. E. (2016). Writing and Writing Difficulties from Primary Grades to College. Learning Disability Quarterly, 39(1), 3-4.

https://doi.org/10.1177/0731948715 592154.

Navehebrahim, M. (2011). Multiliteracies 
Pendas : Jurnal Ilmiah Pendidikan Dasar, ISSN Cetak : 2477-2143 ISSN Online : 2548-6950

Volume IV Nomor 1, Juni 2019

empower learning and teaching engagement. Procedia - Social and Behavioral Sciences, 29, 863-868. https://doi.org/10.1016/i.sbspro.201

\subsubsection{5.}

Özdemir, E., \& Aydın, S. (2015). The Effects of Wikis on Motivation in EFL Writing. Procedia - Social and Behavioral Sciences, 191, 23592363.

https://doi.org/10.1016/j.sbspro.201 5.04.241.

Pardo. (2006). The role of context in learning to teach writing, /http://jte.sagepub.com/content/57/4 /378.full.pdf+html,57(4), hlm.379394.

Sopandi, W., \& Handayani, H. (2019).

The Impact of Workshop on
Implementation of (RADEC) Learning Model on Pedagogic Competency of Elementary School Teachers. International Conference of Innovation in Education (IColE) 178, pp. 7-11.

Sopandi, W. (2017). The quality improvement of learning processes and achievements through the read-answer-discuss-explain-and create learning model implementation. Proceeding 8th Pedagogy International Seminar 2017: Enhancement of Pedagogy in Cultural Diversity Toward Excellence in Education, 8(229), 132-139. 